\title{
Influence of ocean warming and acidification on trace metal biogeochemistry
}

\author{
Linn J. Hoffmann ${ }^{1,2, *}$, Eike Breitbarth ${ }^{1,2}$, Philip W. Boyd ${ }^{3}$, Keith A. Hunter ${ }^{1}$ \\ ${ }^{1}$ Department of Chemistry, University of Otago, PO Box 56, Dunedin 9054, New Zealand \\ ${ }^{2}$ GEOMAR Helmholtz Centre for Ocean Research Kiel, Düsternbrooker Weg 20, 24105 Kiel, Germany \\ ${ }^{3}$ National Institute of Water and Atmosphere Centre of Chemical and Physical Oceanography, Department of Chemistry, \\ University of Otago, PO Box 56, Dunedin 9054, New Zealand
}

\begin{abstract}
Rising atmospheric $\mathrm{CO}_{2}$ concentrations will have profound effects on atmospheric and hydrographic processes, which will ultimately modify the supple and chemistry of trace metals in the ocean. In addition to an increase in sea surface temperatures, higher $\mathrm{CO}_{2}$ results in a decrease in seawater $\mathrm{pH}$, known as ocean acidification, with implications for inorganic trace metal chemistry. Furthermore, direct or indirect effects of ocean acidification and ocean warming on marine biota will affect trace metal biogeochemistry via alteration of biological trace metal uptake rates and metal binding to organic ligands. We still lack a holistic understanding of the impacts of decreasing seawater $\mathrm{pH}$ and rising temperatures on different trace metals and marine biota, which complicates projections into the future. Here, we outline how ocean acidification and ocean warming will influence the inputs and cycling of Fe and other biologically relevant trace metals globally and regionally in high and low latitudes of the future ocean; we discuss uncertainties and highlight essential future research fields.
\end{abstract}

KEY WORDS: Ocean acidification $\cdot$ Ocean warming $\cdot$ Trace metals Resale or republication not permitted without written consent of the publisher

\section{INTRODUCTION}

Rising atmospheric $\mathrm{CO}_{2}$ concentrations affect the marine environment directly via the uptake of $\mathrm{CO}_{2}$ that acidifies the oceans (Caldeira \& Wickett 2003, Doney et al. 2009b) and indirectly via global temperature increase that also results in sea-surface warming. Ocean warming is particularly evident in the Arctic (Wassmann et al. 2011) and in some Antarctic regions (Schofield et al. 2010). Modeling simulations reveal further effects of a changing climate, such as increasing stratification that results in reduced upwelling and wind-driven mixing (Doney 2006), changing wind patterns (Tokinaga et al. 2012), expansion of the areal extent of oxygen minimum zones (Gruber 2011), and changes in the thermohaline circulation (Rahmstorf \& Ganopolski 1999, Boyd \& Doney 2003).

Although there is a wealth of published information on the importance of trace metals and their inputs and cycling in marine systems (Morel \& Price 2003, Boyd \& Ellwood 2010), the impacts of rising atmospheric $\mathrm{CO}_{2}$ on trace metal biogeochemistry are presently difficult to foresee. The role of trace metals for oceanic carbon sequestration, and thus their climate relevance, has received much attention since the seminal work of Martin (1990) and was recently highlighted again by Smetacek et al. (2012). However, investigations into the influence of rising atmospheric $\mathrm{CO}_{2}$ on marine processes and trace metal biogeochemistry still appear as isolated disciplines. This is puzzling, as $\mathrm{pH}$ and temperature are 2 master variables in all chemical and biological processes and therefore intimately link the disciplines of trace metal biogeochemistry, ocean acidification, and sea surface warming.

Dissolved metals in seawater are usually present at low concentrations due to their low solubility (as in the case of $\mathrm{Fe}$ ) and/or because of adsorption onto particles. Seawater $\mathrm{pH}$ and temperature will affect both 
solubility and adsorption of metals, and thus likely change the dissolved concentrations of metals in the future ocean. The inorganic solubility of $\mathrm{Fe}$ is greater in colder waters (Liu \& Millero 2002) but also largely depends on the organic content of seawater. Furthermore, increasing temperatures will increase the rates of all chemical reactions, which should increase ferric oxide and hydroxide precipitation as well as oxide aging with negative effects for dissolved Fe concentrations. A clear dependency of metal solubility upon temperature has not been established for many elements, and therefore quantifications of the effect of rising sea surface temperature (SST) on metal solubility in the future ocean are difficult. On the other hand, the expected decrease in seawater $\mathrm{pH}$ from pre-industrial 8.25 to 7.85 within this century, and of up to 0.7 units by the year 2300 (Caldeira \& Wickett 2003, Jacobson 2005), will significantly affect the inorganic solubility of several trace metals, particularly those forming strong complexes with hydroxide and carbonate ions (Millero et al. 2009). The case of $\mathrm{Fe}$ is the most multifaceted and is discussed here briefly. When seawater $\mathrm{pH}$ falls below 8 , changes in the inorganic speciation result in an increase in the thermodynamic solubility of Fe(III) hydroxide. Based on measurements of Kuma et al. (1996) and Millero (2001), the overall Fe(III) solubility may increase by approximately $460 \mathrm{pmol} \mathrm{\textrm {kg } ^ { - 1 }}$ as a result of the expected drop in seawater $\mathrm{pH}$ from currently 8.10 to 7.85 by the year 2100 . In parallel, Fe(II) is much more soluble than Fe(III) but is unstable at current seawater $\mathrm{pH}$ due to rapid oxidation. Ocean acidification will slow $\mathrm{Fe}$ (II) oxidation rates significantly and thus increase the residence time of Fe(II) (Kuma et al. 1996, Millero 2001, Breitbarth et al. 2010b).

Compared to the well-studied Fe redox reactions in seawater, only a few studies have addressed $\mathrm{Cu}$ redox reactions in the field (Moffett \& Zika 1987, 1988). As for $\mathrm{Fe}$, a shift in $\mathrm{Cu}$ speciation can be expected (Millero et al. 2009). $\mathrm{Cu}$ forms strong carbonate complexes, and the decrease in $\mathrm{CO}_{3}{ }^{2-}$ ions due to ocean acidification will result in an increase in the free $\mathrm{Cu}$ (II) ion concentration (Millero et al. 2009). In parallel, $\mathrm{Cu}$ (II) reduction will increase, while $\mathrm{Cu}(\mathrm{I})$ complexation by chloride and reoxidation kinetics by $\mathrm{H}_{2} \mathrm{O}_{2}$ remain largely unchanged (Millero et al. 1991). It is unclear today whether these changes in the $\mathrm{Cu}$ redox cycle will be of biological relevance. In contrast, $\mathrm{Cd}$ and $\mathrm{Zn}$ are not subjected to a dynamic redox cycle in the surface ocean, and their solubility in seawater is much higher than for Fe(III). The effect of ocean acidification on the inorganic $\mathrm{Cd}$ and $\mathrm{Zn}$ solubility may thus be negligible.
However, the influence of changing ocean acidity and temperature on trace metal biogeochemistry is more complex than a direct $\mathrm{pH} /$ temperature relationship with solubility. Metal solubility is controlled by the interrelationship of inorganic solubility, organic complexation, redox chemistry, and the phytoplankton-trace metal feedback mechanisms (Fig. 1). The majority of the total concentration of bio-active metals such as $\mathrm{Fe}, \mathrm{Co}, \mathrm{Cd}, \mathrm{Cu}, \mathrm{Ni}, \mathrm{Zn}$, and $\mathrm{Pb}$ are not in their inorganic form, but bound to organic complexes. The ligand-bound fraction of metals can be up to $100 \%$ for Co (Saito \& Moffett 2001, Saito et al. 2005), $>99 \%$ for $\mathrm{Fe}$ and $\mathrm{Cu}$ (Sunda \& Hanson 1987 , Coale \& Bruland 1988, Sunda \& Huntsman 1991, Rue \& Bruland 1995), from 50 to 90 and $>98 \%$ for Zn (Bruland 1989, Baars \& Croot 2011), and $>70 \%$ for $\mathrm{Cd}$ (Bruland 1992). Possible effects of rising oceanic $\mathrm{CO}_{2}$ concentrations on organic trace metal ligands will therefore play a major role in overall trace metal bioavailability in the future ocean, but only very few studies have addressed this topic so far. Assessments of ocean acidification effects on marine trace metal chemistry are still largely based on theoretical considerations of inorganic and organic metal speciation and therefore tell us little about potential effects on metal uptake, requirements, toxicity thresholds, and possible biological feedback mechanisms (Millero et al. 2009, Breitbarth et al. 2010a).

In the last decade, an enormous amount of published work on the influence of ocean acidification on marine biota has been assembled (Gattuso \& Hansson 2011). However, publications concerning the interactions of multiple factors such as seawater $\mathrm{pH}$, temperature, and trace metals are scarce but point towards the significance and complexity thereof (Boyd et al. 2010). For example, it has been demon-

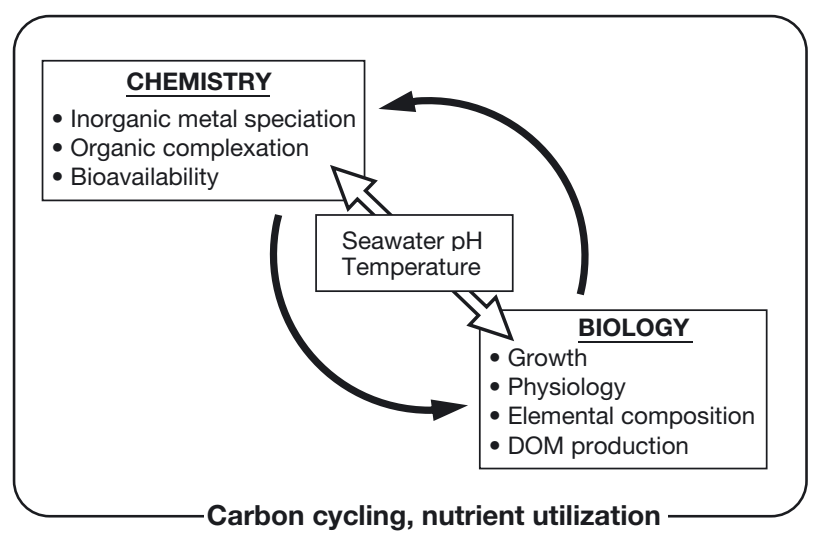

Fig. 1. Predicted relationship between the effects of ocean acidification and warming on trace metal chemistry and phytoplankton biology in seawater 
strated that $\mathrm{N}_{2}$ and $\mathrm{CO}_{2}$ fixation rates as well as growth of the marine unicellular diazotrophic cyanobacterium Crocosphaera only increased with increasing $p \mathrm{CO}_{2}$ if $\mathrm{Fe}$ concentrations were not limiting ( $\mathrm{Fu}$ et al. 2008).

Temperature and Fe have synergistic effects on phytoplankton growth rates in the Ross Sea (Rose et al. 2009). Moreover, King et al. (2011) state that complex feedback mechanisms between vitamin $\mathrm{B}_{12}$ and $p \mathrm{CO}_{2}$ interactions affect the uptake and metal net use efficiency of $\mathrm{Fe}, \mathrm{Co}, \mathrm{Zn}$, and $\mathrm{Cd}$ by Atthyea sp., a subarctic diatom. Under $\mathrm{B}_{12}$-replete conditions and high $p \mathrm{CO}_{2}$, this diatom grew faster, had lower $\mathrm{Fe}, \mathrm{Zn}$, and $\mathrm{Cd}$ quotas, and used the metals more efficiently compared to low $p \mathrm{CO}_{2}$ conditions. Under $\mathrm{B}_{12}$ limitation, however, diatom growth rate was much lower and did not change with changing $p \mathrm{CO}_{2}$. Also, the net use efficiency of $\mathrm{Fe}, \mathrm{Zn}, \mathrm{Co}$, and $\mathrm{Cd}$ decreased with increasing $p \mathrm{CO}_{2}$ under $\mathrm{B}_{12}$ limitation (King et al. 2011). At a higher trophic level, work by LacoueLabarthe et al. (2009, 2011, 2012) suggests potential ecotoxicological impacts of trace metals with seawater warming and decreasing seawater $\mathrm{pH}$ due to altered permeability of egg shells and the embryonic metabolism in the cephalopod species Loligo vulgaris and Sepia officinalis. All of these examples demonstrate the need to consider multiple factors when trying to assess the implications of ocean acidification and warming on the marine ecosystem.
The importance of a multivariate approach especially when investigating essential trace elements is founded in Liebig's law of the minimum (Salisbury \& Ross 1992). For example, changes in Fe bioavailability may not result in increased phytoplankton growth if another nutrient is ultimately limiting. Likewise, ocean acidification effects on phytoplankton growth and nutrient uptake may be masked if nutrient limitation, which in the open ocean is often governed by $\mathrm{Fe}$, is elevated due to contamination artifacts associated with the experimental set-up. Acknowledging this, some groups now have developed 'trace-metal clean' experimental protocols for ocean acidification work (Hoffmann et al. in press).

It seems that decreasing seawater $\mathrm{pH}$ and warming will both influence trace metal-phytoplankton interactions in various ways; however, robust predictions of these interactions are not yet possible. In order to assess the effects of ocean acidification and SST warming on trace metal biogeochemistry in the future ocean, we need to look at how trace metals are supplied, cycled, and lost from the upper ocean. Table 1 summarizes how global change may affect metal input in the future ocean on a global scale, as well as in high- and low-latitude regions. In the following sections, we will discuss the primary factors that control the interplay of temperature, ocean acidification, and trace metals in the ocean and how they might affect marine phytoplankton both globally and regionally.

Table 1. Overview of potential global change effects on trace metal chemistry. TM: trace metal; DOM: dissolved organic matter
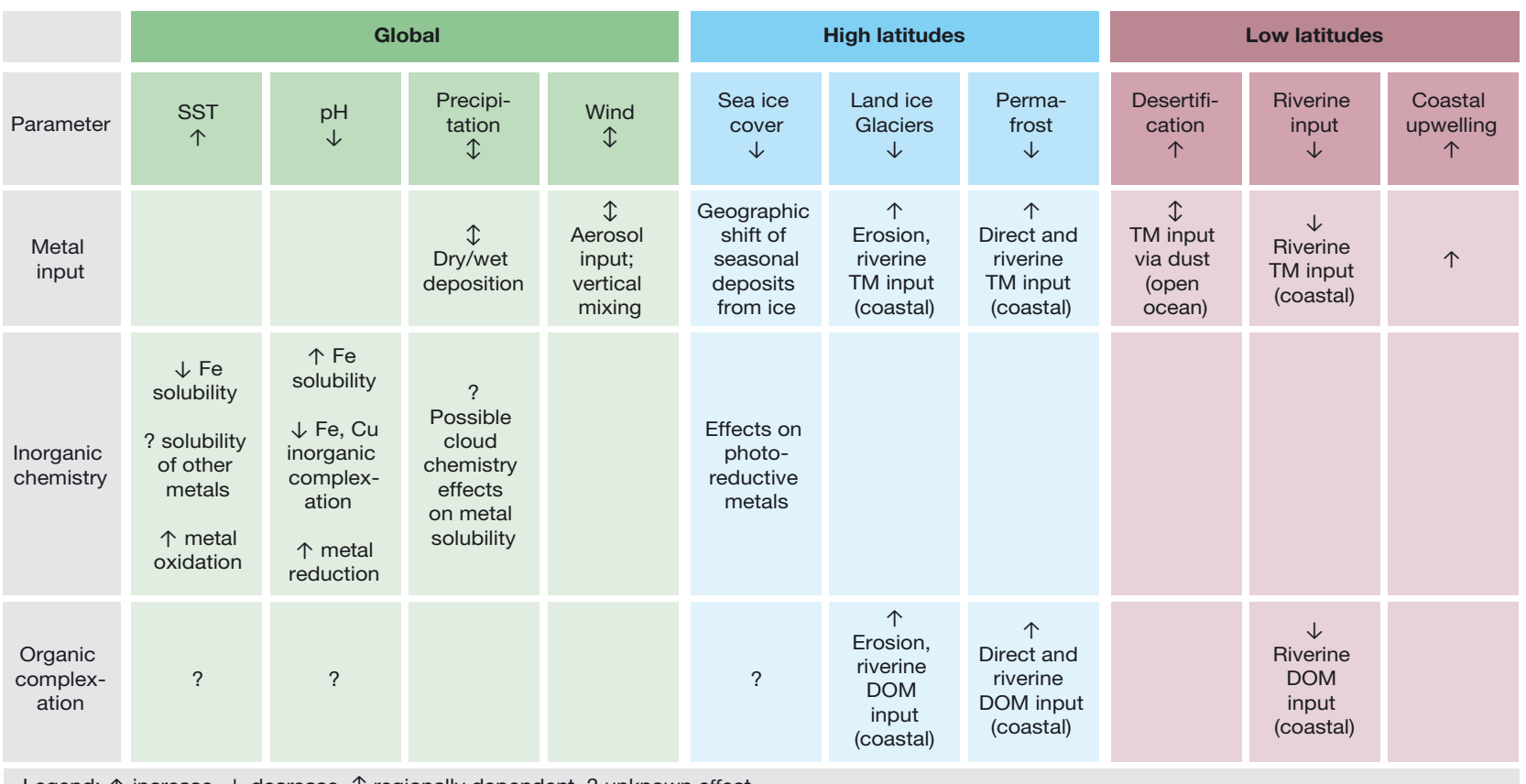

Legend: $\uparrow$ increase, $\downarrow$ decrease, $\downarrow$ regionally dependent, ? unknown effect 


\section{GLOBAL EFFECTS OF CLIMATE CHANGE AND OCEAN ACIDIFICATION ON MARINE TRACE METAL SUPPLY AND CYCLING}

\section{Metal sources}

Climate change is likely to influence global trace metal biogeochemistry by affecting both metal sources and cycling in the future ocean. For surface waters, the main global trace metal inputs are aerosol particles from desert dust (Jickells et al. 2005), anthropogenic sources (Sedwick et al. 2007, Sholkovitz et al. 2009), and volcanic eruptions (Olgun et al. 2011). In coastal regions, riverine inputs and upwelling of trace metal-rich deep water play an additional important role (Boyd 2009). Sediments are a major source of trace metals in shelf waters (e.g. Laës et al. 2007, Ussher et al. 2007), and the 'island wake' effect is of local importance in remote ocean systems (Blain et al. 2007). It has been suggested recently that trace metals from deep-sea hydrothermal vents can potentially reach surface waters via ocean circulation allied to an excess of organic compounds that bind to and stabilize the metals in hydrothermal fluids (Sander \& Koschinsky 2011).

Climate change will potentially influence global dust and riverine trace metal inputs into the ocean, but accurate predictions are not yet possible (Boyd \& Ellwood 2010). Global dust models predict scenarios that vary from a $60 \%$ decrease to a $3.8 \%$ increase in dust emissions during the 21st century (Mahowald \& Luo 2003, Tegen et al. 2004, Woodward et al. 2005, Stier et al. 2006), making robust projections about future changes in dust as a trace metal source a major challenge. Model predictions suggest an increase in precipitation for the monsoon regimes, over the tropical Pacific, as well as at high latitudes, while a decrease in precipitation is predicted in the subtropics (Meehl et al. 2007). Therefore, riverine trace metal inputs are likely to change significantly on a global scale with large regional differences depending on a range of factors, such as complex interactions of their terrestrial sources, redox processes, and colloid chemistry in estuaries.

The supply of trace metals, in particular from aerosols, will further be influenced by the projected changes in $\mathrm{CO}_{2}$ and other anthropogenically-influenced gases. Increasing atmospheric concentrations of carbon dioxide, sulfur dioxide, and nitrogen oxides decrease the $\mathrm{pH}$ of cloud water and result in acid rain (Badr \& Probert 1993, Bogan et al. 2009, Vahedpour \& Zolfaghari 2011). The direct contribution of sulfur and nitrogen gases to ocean acidification will be neg- ligible (Hunter et al. 2011), but the effect on atmospheric trace metal inputs could be significant. As in seawater, a lower $\mathrm{pH}$ of cloud water results in increased solubility of trace metals from aerosol particles such as desert dust or volcanic ash with potentially significant effects for the net flux of trace metals from these sources to the future ocean (Desboeufs et al. 2001). Mahowald et al. (2009) estimated that the higher acidity in the atmosphere caused by human activities may double the bioavailable Fe in the ocean via increased solubility from desert dust.

On a global scale, model predictions suggest a future increase in precipitation as well as water vapor and evaporation, while regional variations are pronounced (Meehl et al. 2007). Together, altered patterns in wind and precipitation, as well as riverine transport, will ultimately modify the supply of trace metals to the open ocean. The effects of these physicochemical changes on marine productivity and biogeochemical cycling may be profound (Boyd \& Doney 2003, Feely et al. 2004, Jickells et al. 2005, Orr et al. 2005).

\section{Inorganic metal speciation}

As mentioned above, the inorganic speciation of metals will be altered by ocean warming and ocean acidification. One example thereof is the observed increase in Fe(II) concentrations and Fe(II) half-life times under lower $\mathrm{pH}$ in a coastal mesocosm experiment (Breitbarth et al. 2010b). In addition, changes in surface ocean stratification will likely have effects on particle residence times in the euphotic zone. When stratification increases, there is less mixing with deeper waters, which means that particles in the surface mixed layer may reside for longer in this stratum (Doney 2006). This would increase the mean light intensity to which particles in the surface mixed layer are exposed, with possible implications for photochemical metal redox dynamics. For example, increased light and temperature increase Mn oxide dissolution rates (Sunda \& Huntsman 1994). Furthermore, the photoreduction of Fe(III) complexes increases under higher light intensities, resulting in higher Fe(II) concentrations (Kuma et al. 1995). In addition, the photosynthetic apparatus of marine phytoplankton is downregulated under higher light intensities, resulting in lower Fe requirements (Sunda \& Huntsman 1997, Maldonado et al. 1999, Feng et al. 2010). However, stronger stratification will also lead to increased warming of the surface waters, which may decrease Fe(II) concentrations due to higher 
reoxidation rates, as observed in the Gulf of Aquaba (Shaked 2008). Lower Fe requirements for marine phytoplankton, as a result of elevated light intensities, are thus mainly to be expected in colder oceanic regions (Sunda \& Huntsman 2011). Likewise, ocean acidification will affect the redox speciation of $\mathrm{Cu}$, yielding a larger $\mathrm{Cu}$ (I) fraction (Millero et al. 2009). The potential biological implications thereof are unknown today.

In general, even slight changes in the bioavailability of $\mathrm{Fe}$ and $\mathrm{Cu}$ may have profound effects for marine ecosystems, as these metals are known to interact with each other. $\mathrm{Cu}$ is needed by some marine phytoplankton for sufficient $\mathrm{Fe}$ acquisition (Peers et al. 2005, Wells et al. 2005, Maldonado et al. 2006, Annett et al. 2008), and $\mathrm{Cu}$ requirements of natural phytoplankton communities increase under Fe limitation (Semeniuk et al. 2009). On the other hand, $\mathrm{Cu}$ is a potentially toxic metal whose toxicity to marine phytoplankton is strongly regulated by organic ligand complexation.

\section{Organic metal speciation}

Organic trace metal complexation in seawater is controlled by the functional groups within dissolved organic matter, including phytoplankton exudates, siderophores produced by heterotrophic bacteria, and bioremineralization products (Boyd \& Ellwood 2010, Breitbarth et al. 2010a). To date, research on trace metal bioavailability has focused on measurements of ligand concentrations and ligand binding strength in natural waters, and metal uptake in controlled laboratory experiments using metal chelators. Studies addressing ocean acidification effects on organic ligand binding are rare. In a first study, Shi et al. (2010) investigated the effect of $\mathrm{pH}$ on Fe uptake from 3 Fe-ligand complexes with different functional groups. They found reduced Fe uptake by marine phytoplankton under lower $\mathrm{pH}$ in EDTA- and DFOBbuffered media but no $\mathrm{pH}$ effect on Fe uptake from the siderophore Fe-Azotochelin. This was expected, as the catechol groups of Azotochelin are protonated in seawater and thus the free $\mathrm{Fe}$ concentration should not be affected by changes in seawater $\mathrm{pH}$ (Shi et al. 2010). In the case of EDTA, cellular Fe acquisition decreases with decreasing seawater $\mathrm{pH}$ as the dissociation of Fe-EDTA (and any chelator with acidic binding groups that are not protonated in seawater) becomes less favored at low $\mathrm{pH}$ due to reduced competition with $\mathrm{OH}^{-}$for Fe chelation, and thus the $\mathrm{Fe}^{\prime}$ concentration decreases (Stumm \& Mor- gan 1996). However, as acknowledged by Shi et al. (2010), Fe' uptake from Fe-EDTA is a simplistic scenario in which $\mathrm{Fe}^{\prime}$ is the only bioavailable form of Fe. Such an approach has limited applications to the open ocean, as natural organic ligands possess a variety of metal binding sites (Barbeau et al. 2003) with different $\mathrm{H}^{+}$stoichiometries (Sillén \& Martell 1971, Breitbarth et al. 2010a). The observed decrease in Fe uptake from Fe-DFOB under lower $\mathrm{pH}$ was not caused by a $\mathrm{pH}$ effect on the dissociation of the FeDFOB complex, as this is not affected by seawater $\mathrm{pH}$ (Shi et al. 2010). Rather, this was most likely due to $\mathrm{pH}$ effects on the enzymatic cell surface reduction of the Fe-DFOB complex (Shi et al. 2010). In addition, a substantial body of work points towards the multiplicity of Fe uptake mechanisms in marine phytoplankton, which include models of ligand-bound Fe (FeL) uptake, cell surface reduction of the FeL complex, and direct uptake of Fe(II) (Hutchins et al. 1999, Maldonado \& Price 1999, Shaked et al. 2005, Salmon et al. 2006, Morel et al. 2008). Therefore, the diverse range of chemical and biological processes in marine trace metal biogeochemistry, and how they each will be altered by ocean acidification, is likely to be multifaceted and complex.

Short-term (1 to 2 h) Fe uptake experiments with the coastal diatom Thalassiosira weissflogii in natural seawater did not show significant differences between different $\mathrm{pH} / \mathrm{pCO}$ treatments within the same water mass (Shi et al. 2010). However, a body of literature is evolving on physiological effects of ocean acidification on marine phytoplankton (Engel et al. 2004, Doney et al. 2009a, Hutchins et al. 2009, Boyd et al. 2010). Therefore, experiments over periods long enough for phytoplankton to grow could result in significant impacts on organic Fe complexation. Results from a coastal mesocosm $\mathrm{CO}_{2}$ enrichment experiment show 2 to $3 \mathrm{nM}$ higher dissolved Fe concentrations under lower $\mathrm{pH}$ compared to the midand high $\mathrm{pH}$ treatments (Breitbarth et al. 2010b). This large difference cannot be solely explained by an increased inorganic $\mathrm{Fe}$ solubility under lower $\mathrm{pH}$ (Millero et al. 2009), and thus $\mathrm{pH}$ effects on the organic Fe complexation are one likely explanation next to $\mathrm{pH}$ effects on colloid formation, Fe chelation, and $\mathrm{Fe}$ hydroxide precipitation (Breitbarth et al. 2010b).

While the effect of ocean acidification on heterotrophic bacterial growth seems to be small (Liu et al. 2010, Weinbauer et al. 2011), bacterial enzymatic activity and polysaccharide degradation increases under lower seawater $\mathrm{pH}$ in coastal waters (Grossart et al. 2006, Piontek et al. 2010). Increasing tempera- 
tures have been shown to increase bacterial growth, production, and respiration (Vaqué et al. 2009, Kritzberg et al. 2010). The direct effects thereof upon trace metal bioavailability have not been assessed at present, but it is possible that these mechanisms will also affect the siderophore production by heterotrophic bacteria with consequent implications for Fe bioavailability in the future ocean. Moreover, changes in organic complexation, either via shifts in ligand: $\mathrm{H}^{+} / \mathrm{OH}^{-}$stoichiometry or as an effect of ligand concentration changes, should also affect Fe retention rates in surface waters (Sunda 2010).

The Fe(III)-binding groups of marine siderophores can be hydroxamate, catecholate, or $\alpha$-hydroxy carboxylate moieties (Barbeau et al. 2003). While hydroxamate and catecholate groups are photochemically resistant when bound to Fe(III), $\alpha$-hydroxy carboxylate groups undergo light-induced ligand oxidation and reduction of Fe(III) to Fe(II) (Barbeau et al. 2001, 2003). Increased mean light intensities in the predicted future shallower surface mixed layers (Doney 2006) would thus enhance the photolysis of some organic Fe(III) complexes and increase reactive Fe(II) in surface seawater. Cu-binding ligands differ from Fe-binding ligands in that they can be directly produced by some marine phytoplankton species when exposed to higher concentrations of $\mathrm{Cu}$ (and other toxic metals such as Cd and Zn) (Ahner \& Morel 1995, Moffett \& Brand 1996, Croot et al. 2000, Ahner et al. 2002, Dupont \& Ahner 2005). Thereby, the ligand can be released into the water and bind $\mathrm{Cu}$ (or other toxic metals such as Cd and Zn) extracellularly (Moffett \& Brand 1996, Croot et al. 2000, Dupont \& Ahner 2005), or the metals are taken up into the cell and detoxified by intracellular binding to the ligand (Ahner et al. 2002, Dupont et al. 2004). These thiols are low molecular weight sulfhydryl-containing compounds such as glutathione and phytochelatin. Both glutathione and phytochelatin bind $\mathrm{Cd}, \mathrm{Cu}$, and $\mathrm{Pb}$ via sulfhydroxyl coordination (Rabenstein 1989, Strasdeit et al. 1991). Louis et al. (2009) described a decrease in the interaction between organic ligands and $\mathrm{Cu}(\mathrm{II})$ when seawater $\mathrm{pH}$ fell below 8. As a result, the inorganic $\mathrm{Cu}$ fraction increased with decreasing $\mathrm{pH}$, similar to what was described earlier for fresh waters (Averyt et al. 2004). It is unknown so far whether $\mathrm{Cu}$ ligand production will be affected by ocean acidification and warming and what the effects for $\mathrm{Cu}$ toxicity would be. Intracellular $\mathrm{Cu}$ binding is unlikely to be directly affected by surrounding seawater $\mathrm{pH}$ but could possibly be indirectly affected via ocean acidification and warming effects on phytoplankton physiology.
A recent study described the effect of $\mathrm{pH}$ on the uptake of $\mathrm{Zn}$ and $\mathrm{Cd}$ in marine phytoplankton (Xu et al. 2012). Here, short-term (3 to 4 h) $\mathrm{Zn}$ and $\mathrm{Cd}$ uptake in natural phytoplankton assemblages decreased with decreasing $\mathrm{pH}$ in contrast to experiments with single metal chelators in the laboratory. The authors concluded that in natural systems, Zn and $\mathrm{Cd}$ bioavailability is lower under lower $\mathrm{pH}$, which they explained by the potential interaction of strong and weak ligands in natural waters. These results illustrate that care must be taken when extrapolating results from laboratory experiments using artificial metal chelators to the field.

For future research, the interplay between SST, $\mathrm{pH}$, and dissolved organic matter (DOM) content of seawater and their effects on metal bioavailability needs to be established in order to better understand the effect for metal uptake by marine phytoplankton at a global level. In the context of ocean acidification and ocean warming effects on trace metal biogeochemistry, it is important to establish a holistic view of the many facets of trace metal chemistry. Future predictions of the nature of trace metal-phytoplankton interactions are difficult, as most studies have so far focused on Fe and neglected possible impacts of other metals. Because of growing evidence that the interplay of a particular metal with other metals, as opposed to the bioavailable concentration of one metal alone, will determine its biological impact (Sunda \& Huntsman 1983, 1996, 2000, Peers et al. 2005, Maldonado et al. 2006), we have to move away from the dominant focus on $\mathrm{Fe}$ as a sole controlling trace metal in marine biogeochemistry. In addition to the importance of $\mathrm{Cu}$ for Fe uptake, the interplay between $\mathrm{Cd}, \mathrm{Fe}$, and $\mathrm{Zn}$ might have important ramifications with regard to the effects of ocean acidification. $\mathrm{Zn}$ is needed in the enzyme carbonic anhydrase in marine phytoplankton and can be substituted by $\mathrm{Cd}$ and/or Co under Zn limitation (Price \& Morel 1990). Low Zn concentrations have been shown to decrease $\mathrm{HCO}_{3}{ }^{-}$uptake and thus limit phytoplankton growth (Morel et al. 1994, Buitenhuis et al. 2003). Higher $p \mathrm{CO}_{2}$ in a more acidic ocean should lower the Zn requirements of marine phytoplankton and would thus also lower the need for substitution by $\mathrm{Cd}$ (Cullen et al. 1999).

The 'kink' in the $\mathrm{Cd}: \mathrm{PO}_{4}$ relationship at intermediate $\mathrm{PO}_{4}$ concentrations $\left(\sim 1.3 \mu \mathrm{mol} \mathrm{kg}{ }^{-1}\right)$ and deviations thereof are also associated with Fe chemistry (Cullen 2006). Experiments have shown that $\mathrm{Cd}$ interferes with the uptake of $\mathrm{Fe}(\mathrm{II})$ and that the $\mathrm{Cd}$ :C and $\mathrm{Cd}: \mathrm{P}$ ratios increase under Fe limitation and decrease with increasing Fe (Cullen et al. 2003, Lane et 
al. 2008, 2009). It is not clear, though, how important phylogenetic differences in the Cd uptake are in this context (Quigg et al. 2003), or what the interrelationship of $\mathrm{Cd}, \mathrm{Fe}$, and $\mathrm{Zn}$ in a warmer, more acidic ocean may be. Since changes in the biogeochemistry of Fe and Zn may likewise affect Cd chemistry in seawater, this also complicates the use of $\mathrm{Cd}$ as a tracer for past seawater nutrient concentrations (Cullen 2006). Furthermore, Cd and Zn appear to compete for the same ligands in fresh water (Sander et al. 2007); however, investigations on this topic are lacking for seawater.

In summary, ocean acidification and ocean warming will ultimately alter metal biogeochemistry on multiple levels, from affecting trace metal sources, via primary chemical effects on inorganic trace metal speciation, through to physiological effects on microbial cellular metal acquisition, and finally as a product of potential biological feedback mechanisms of heterotrophic bacteria and phytoplankton ecophysiology and altered community structure.

\section{INTERPLAY OF TRACE METAL SUPPLY, OCEAN ACIDIFICATION, AND TEMPERATURE AT HIGH LATITUDES}

The variability in the projections from recent global dust and precipitation model simulations points to the need for a more regional view to better identify future changes in trace metal supply. In polar regions, the main sources of trace metals to the ocean are aerosol deposition and ice melting, as well as riverine input in the Arctic (Wagener et al. 2008, Shaw et al. 2011, Boyd et al. 2012, Klunder et al. 2012; Table 1). Asian dust fluxes that can reach the North Pacific are expected to decrease markedly in the future (Tsunematsu et al. 2011), but as mentioned earlier, these fluxes are difficult to predict on a basin scale because of regional differences in soil moisture and vegetation (Ravi et al. 2011).

Ocean acidification and warming have already resulted in distinct changes of the polar marine ecosystem. Sea ice cover and the areal extent of land ice glaciers have decreased significantly in recent years both in the Arctic and Antarctic (Anisimov et al. 2007, Perovich \& Richter-Menge 2009, Comiso 2012), and this trend is expected to increase in the near future. Further, in the Arctic Ocean, increasing $p \mathrm{CO}_{2}$ concentrations and sea ice melting have already resulted in aragonite undersaturation (Yamamoto-Kawai et al. 2009).
The result of rapid ice melting in both regions is an increased input of fresh water, which, together with an increase in SST, will enhance stratification at high latitudes and reduce the exchange with nutrient- and trace metal-rich deeper waters with impacts on deepwater formation and the thermohaline circulation (Marsland et al. 2007, Wassmann \& Reigstad 2011). An additional consequence of melting ice in both polar regions is an effect on the light climate of the mixed layer. A reduction in Arctic sea ice cover strongly increases the light penetration into surface waters and thus will influence the photochemical redox-processing of trace metals. In Antarctic waters, where light limitation is mainly caused by deep mixing, the effects will probably not be as pronounced as in the Arctic. However, Boyd et al. (2008) predicted a shoaling of mixed layer depths in the Southern Ocean, which will also increase the mean light intensity in surface waters. In the case of $\mathrm{Fe}$, increased photochemical Fe(III) reduction will lead to a larger pool of Fe(II) supported by a higher residence time due to slower oxidation rates at lower $\mathrm{pH}$ and cold temperatures (Kuma et al. 1995, Sunda \& Huntsman 2003).

A further consequence of increased melting of drifting Arctic sea ice, which is formed in the shallow coastal zones and contains entrained sediments, may be a major input of Fe, other trace metals, and terrestrial organic matter to offshore waters of the Arctic Ocean. It is suggested that Fe incorporated in sea ice and subsequently released with meltwaters may also contribute to observed intense ice edge blooms (Hölemann et al. 1999, Measures 1999, Fitzwater et al. 2000). Similar processes have been described for the Antarctic (van der Merwe et al. 2011), and it has been suggested that particularly the role of icebergs for metal supply to the open ocean may increase with the decline of Antarctic ice shelves (Lin et al. 2011). However, Lannuzel et al. (2011) suggested that seawater is the main source for metal accumulation in Antarctic sea ice and that seasonal melt mainly affects Fe input into seawater. Hendry et al. (2008) showed increased $\mathrm{Cd}$ in coastal Antarctic waters from terrestrial and continental shelf sediments with implications for the local $\mathrm{Cd}: \mathrm{PO}_{4}$ ratio. Their results suggest that sea ice cover influences the metal content of Antarctic deep water.

An important factor that will most likely influence the organic trace metal complexation in the Arctic Ocean is permafrost melting. A significant reduction of the permafrost regions around the Arctic Ocean is expected by the end of this century (Delisle 2007, Lawrence et al. 2008). In its 2007 report, the Intergovernmental Panel on Climate Change emphasized that '[t]he most sensitive regions of permafrost degrada- 
tion are coasts with ice-bearing permafrost that are exposed to the Arctic Ocean' (Lemke et al. 2007, p. 372). However, no information about potential effects of meltwater runoff on marine ecosystems is given. Permafrost melting will introduce nutrients, organic substances, and trace metals from land into the sea in a manner that is comparable to spring snowmelt (Rember \& Trefry 2004). As the Arctic Ocean is $\mathrm{N}$ limited as a result of denitrification in the Pacific Ocean (Yamamoto-Kawai et al. 2006), the input of nitrate will likely have a significant effect on Arctic primary productivity. Further, an increased input of organic substances could increase or decrease the bioavailability of trace metals in the Arctic Ocean via changes in their organic complexation. This could further affect the productivity of coastal ecosystems and thus may have serious consequences for the arctic marine biogeochemistry. Arrigo \& van Dijken (2011) reported that the total annual net primary production (NPP) in the Arctic increased by $20 \%$ between 1998 and 2009, and the authors concluded that this was mainly caused by a reduction in sea ice cover and a subsequent increase in light intensity. The possibility that at least part of this increase in NPP could also be influenced by an increase in metal supply was not discussed, but the authors stated that: '[n]utrient fluxes into Arctic surface waters need to be better understood to determine if these projected increases are sustainable' (Arrigo \& van Dijken 2011, p. 1).

Trace metal cycling is further strongly affected by the metal uptake and downward export of biota. Climate-change driven alterations in polar phytoplankton and bacterial species composition as reported by Tortell et al. (2008) and productivity might therefore have significant implications for marine trace metal cycling in the future. Phytoplankton growth is limited by Fe supply (and light) in the Southern Ocean and the subarctic Pacific. When Fe is not limiting, temperature can have a significant additional effect on diatom growth (Rose et al. 2009). Climate-related changes in the bioavailability of Fe (and other trace metals) as discussed above might therefore have strong implications for the phytoplankton community at high latitudes, especially in combination with increasing SST.

\section{INTERPLAY OF TRACE METAL SUPPLY, OCEAN ACIDIFICATION, AND TEMPERATURE AT LOW LATITUDES}

At low latitudes, coastal upwelling, aerosol deposition, and riverine input are the major sources of trace metals to the surface oceans (Landry et al. 1997,
Mackey et al. 2002, Mahowald et al. 2005, TovarSanchez et al. 2006). Riverine trace metal inputs are likely to change significantly as a result of climate change-driven effects on rainfall in these areas. In general, models predict a decrease in rainfall in subtropical regions and an increase in some equatorial regions of east Africa and Asia (Meehl et al. 2007).

Coastal upwelling brings nutrient- and trace metalrich deep water to the surface ocean at low latitudes. Due to climate change, upwelling events are expected to become less frequent but stronger and longer in duration (Bakun 1990, Iles et al. 2012). Temperature and seawater $\mathrm{pH}$ shifts are expected to be less extreme at low latitudes versus high latitudes (Gruber 2011). Therefore, ocean acidification and ocean warming effects on the inorganic metal solubility are likely to be less important at low latitudes. On the other hand, the areal extent of oxygen minimum zones at high and low latitudes has already expanded (Whitney et al. 2007, Stramma et al. 2008). Future modeling predictions indicate that this process will be more pronounced in the low-oxygen regions at low latitudes (Gruber 2011), which will play an important role for nutrient and metal cycling in these regions. Oxygen minimum zones harbor a large amount of Fe in its reduced form Fe(II) that would otherwise rapidly precipitate as Fe(III) and thus get lost from the upper ocean Fe cycle (Fig. 2). Oxygen minimum zones could be a source of Fe(II) for surface waters as discussed for the Baltic Sea (Breitbarth et al. 2009). Paralleled by their role for $\mathrm{P}$ and Mn cycling (Turnewitsch \& Pohl 2010), the regional importance of oceanic oxygen minimum zones for Fe cycling could therefore increase in the future. Similar to $\mathrm{Fe}, \mathrm{Cu}$ reduction is higher under low oxygen conditions, and therefore $\mathrm{Cu}(\mathrm{I})$ concentrations could be higher here.

The reduced freshwater input into the future oceans in subtropical regions will ultimately also reduce the amount of DOM that is transported to the oceans. Therefore, organic trace metal complexation may decrease here. Whether phytoplankton/bacterial feedback mechanisms could counteract this, e.g. by an increased production of metal-binding ligands, remains speculative, but these mechanisms could play a role if the bioavailable fraction of essential metals becomes limiting.

A reduced input of DOM could also reduce the substrate availability for marine bacteria and subsequently their trace metal ligand production. On the other hand, ocean acidification has been shown to increase the activity of some microbial enzymes, which might result in enhanced polysaccharide pro- 


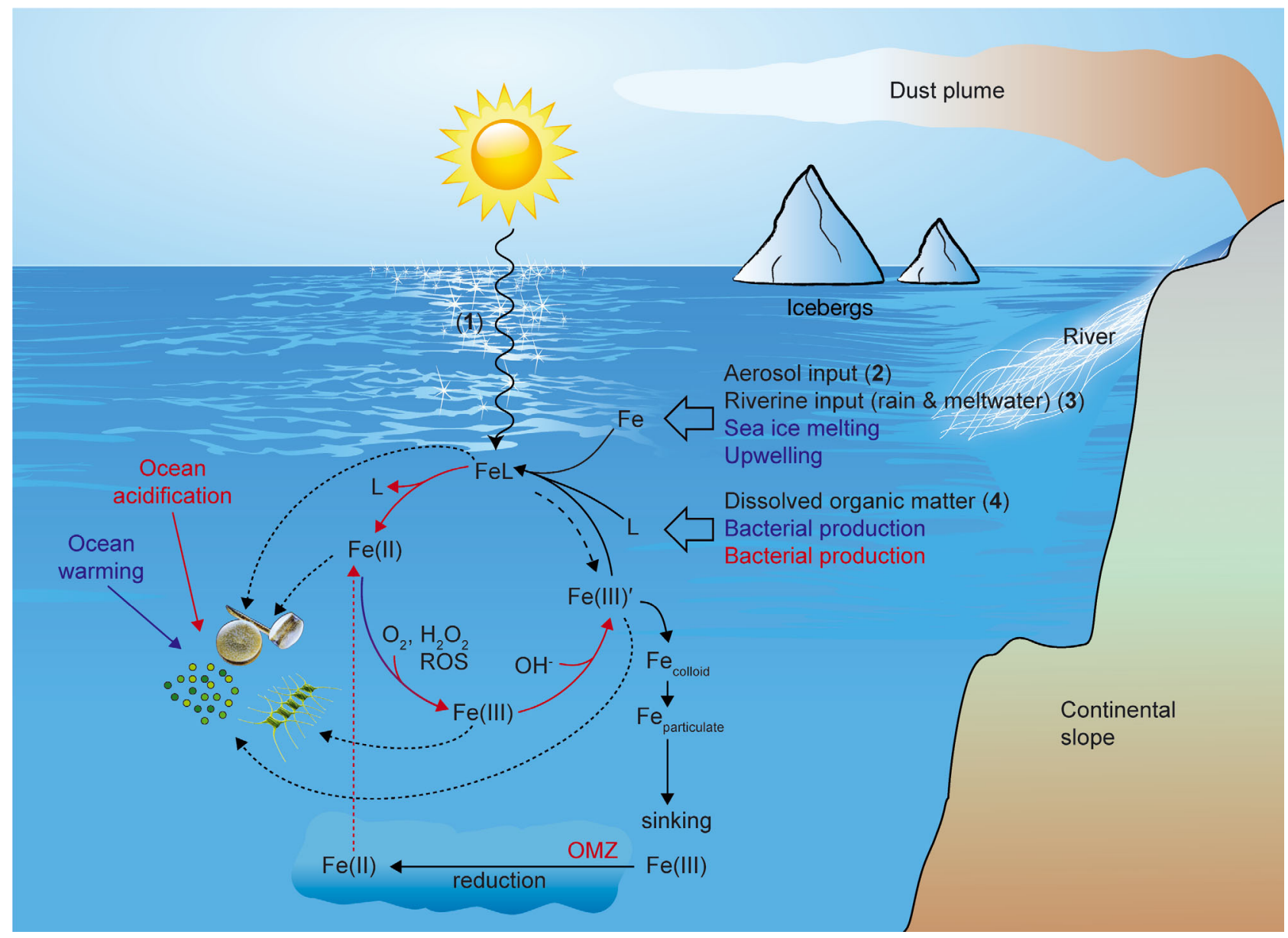

Fig. 2. Direct effects of ocean acidification (red) and ocean warming (blue) on Fe chemistry in seawater. Ocean acidification and ocean warming both influence phytoplankton and bacterial physiology with possible effects for biological Fe uptake and ligand production. Further climate change factors that may influence the marine Fe cycle are (1) changes in stratification and the effects thereof upon light climate, (2) changes in the input of dissolved organic matter, (3) changes in the input of Fe from aerosol particles, and (4) riverine inputs. FeL: ligand-bound iron; L: ligand; Fe(III)': sum of all inorganic Fe(III) species; OMZ: oxygen minimum zone; ROS: reactive oxygen species. Iron cycle redrawn after Sunda (2001), Croot et al. (2005), and Breitbarth et al. (2009)

cessing in the future surface ocean (Piontek et al. 2010). However, effects of ocean acidification for marine microorganisms are often contradictory (Weinbauer et al. 2011), and implications for future trace metal cycling are thus difficult to predict.

At low latitudes, diazotrophic phytoplankton are a major group within the phytoplankton community (Boyd et al. 2010). Both carbon and nitrogen fixation rates of the dominant nitrogen-fixing cyanobacterium Trichodesmium are higher under lower seawater pH (Barcelos e Ramos et al. 2007, Hutchins et al. 2007, 2009, Levitan et al. 2007). Increasing growth rates will further increase the cellular Fe demands of nitrogen fixers, which are already higher compared to other phytoplankton groups (Kustka et al. 2003). This could result in a further increase in Fe limitation of $\mathrm{N}_{2}$ fixation in the future ocean. This is supported by observations that nitrogen fixation rates do not increase under high $p \mathrm{CO}_{2}$ when $\mathrm{Fe}$ concentrations are depleted (Fu et al. 2008, Law et al. 2012).

Overall, increased upwelling, changes in dust deposition, and reduced riverine input will expose marine ecosystems at low latitudes to a multitude of environmental stressors in the future. Today, it is impossible to predict how these will influence the trace metal budget of these waters, but their implications for marine productivity are highly likely.

\section{CONCLUSIONS}

Understanding the potential effects of global change on trace metal biogeochemistry requires an integrated, multidisciplinary approach combining tra- 
ditionally segregated fields of geochemistry, physical oceanography, biology, and marine trace metal chemistry. The abiotic effects of ocean acidification and warming cascade into interwoven basic processes of marine biogeochemistry which need to be addressed individually as well as on a system level. These are as follows: (1) seawater $\mathrm{pH}$ and temperature effects on inorganic trace metal complexation, redox reactions, precipitation, and oxide aging; (2) seawater $\mathrm{pH}$ and temperature effects on organic metal complexation and redox cycling; (3) seawater $\mathrm{pH}$ and temperature effects on microbial community composition, growth, organic ligand production, phytoplankton metal uptake, requirements, and toxicity thresholds; (4) changing bioavailability of trace metals to marine primary producers as a result of (1), (2), and (3); and (5) potential biological feedback mechanisms on all of the above (Fig. 1).

We have illustrated how several environmental factors at high versus low latitudes may affect trace metal biogeochemistry in the future and how large the uncertainties of these estimations still are. However, studying these aspects results in significant methodological challenges. While recent advances in multi-element trace metal analytical protocols allow for a much improved sample throughput with excellent accuracy and precision (Milne et al. 2010, Biller \& Bruland 2012), detailed metal speciation studies still require manual titrations of the metal of interest versus a competing ligand added to the seawater sample. Some working groups have developed automated protocols (S. Sander pers. comm.), which represent a great advance for sample processing of the essential organic speciation measurements. However, trace metal concentration and speciation methods still have in common the approach that the analytical solution is buffered to a standard measurement $\mathrm{pH}$ and measurements are performed at room temperature, making their application for ocean acidification research difficult. Refined protocols are thus needed to determine metal-organic interactions at different seawater $\mathrm{pH}$ and temperatures.

During its emerging phase, the ocean acidification research field was hindered by a lack of consensus on methodological issues, which has now been overcome by a community agreement in the form of a 'Guide to best practices for ocean acidification research and data reporting' (Riebesell et al. 2010). It would be unfortunate if the evolution of the interdisciplinary ocean acidification field (or in a broader context, multiple ocean change effects) and trace metal biogeochemistry, have to undergo a similarly redundant process. As an example, while performing constant $\mathrm{pH}$ monitoring during a trace-metal-clean phytoplankton incubation experiment, we observed that the acid cleaning treatment of the incubation bottles had lowered the seawater $\mathrm{pH}$ by $\sim 0.2$ units in the control treatment (Hoffmann et al. in press). A bottle pre-conditioning step with seawater was required, even though the material (LDPE) was rigorously rinsed with purified water after the last acid cleaning step. This effect likely went unnoticed and provided an accidental ocean acidification treatment in many previous trace metal clean seawater incubations. A full characterization of the seawater carbonate system throughout experiments is advised in the aforementioned guide (Riebesell et al. 2010). A community-based agreement for interdisciplinary ocean acidification-trace metal biogeochemical research that adapts this guide is needed to define suitable standards for future studies.

Acknowledgements. L.J.H. and E.B. acknowledge funding by the German Research Foundation (DFG) grants HO4217/1 and BR-3794/1. The authors thank S. Sander and R. Strzepek for discussion and comments on an earlier version of this manuscript, L. Bucke for help with figure editing and four anonymous reviewers for helpful comments.

\section{LITERATURE CITED}

Ahner BA, Morel FMM (1995) Phytochelatin production in marine algae. 2. Induction by various metals. Limnol Oceanogr 40:658-665

> Ahner BA, Wei L, Oleson JR, Ogura N (2002) Glutathione and other low molecular weight thiols in marine phytoplankton under metal stress. Mar Ecol Prog Ser 232: 93-103

Anisimov OA, Vaughan DG, Callaghan TV, Furgal C and others (2007) Polar regions (Arctic and Antarctic). In: Parry ML, Canziani OF, Palutikof JP, van der Linden PJ, Hanson CE (eds) Climate Change 2007: impacts, adaptation and vulnerability. Contribution of Working Group II to the Fourth Assessment Report of the Intergovernmental Panel on Climate Change. Cambridge University Press, Cambridge, p 653-685

Annett AL, Lapi S, Ruth TJ, Maldonado MT (2008) The effects of $\mathrm{Cu}$ and $\mathrm{Fe}$ availability on the growth and $\mathrm{Cu}: \mathrm{C}$ ratios of marine diatoms. Limnol Oceanogr 53:2451-2461

Arrigo KR, van Dijken GL (2011) Secular trends in Arctic Ocean net primary production. J Geophys Res 116, C09011, doi:10.1029/2011JC007151

Averyt KB, Kim JP, Hunter KA (2004) Effect of pH on measurement of strong copper binding ligands in lakes. Limnol Oceanogr 49:20-27

Baars O, Croot PL (2011) The speciation of dissolved zinc in the Atlantic sector of the Southern Ocean. Deep-Sea Res II 58:2720-2732

Badr O, Probert SD (1993) Environmental impacts of atmospheric nitrous oxide. Appl Energy 44:197-231

Bakun A (1990) Global climate change and intensification of coastal upwelling. Science 247:198-201 
Barbeau K, Rue EL, Bruland KW, Butler A (2001) Photochemical cycling of iron in the surface ocean mediated by microbial iron(III)-binding ligands. Nature 413: 409-413

Barbeau K, Rue EL, Trick CG, Bruland KT, Butler A (2003) Photochemical reactivity of siderophores produced by marine heterotrophic bacteria and cyanobacteria based on characteristic Fe(III) binding groups. Limnol Oceanogr 48:1069-1078

> Barcelos e Ramos JBE, Biswas H, Schulz KG, LaRoche J, Riebesell U (2007) Effect of rising atmospheric carbon dioxide on the marine nitrogen fixer Trichodesmium. Global Biogeochem Cycles 21, GB2028, doi:10.1029/ 2006GB002898

> Biller DV, Bruland KW (2012) Analysis of Mn, Fe, Co, Ni, Cu, $\mathrm{Zn}, \mathrm{Cd}$, and $\mathrm{Pb}$ in seawater using the Nobias-chelate PA1 resin and magnetic sector inductively coupled plasma mass spectrometry (ICP-MS). Mar Chem 130-131:12-20

Blain S, Quéguiner B, Armand L, Belviso S and others (2007) Effect of natural iron fertilization on carbon sequestration in the Southern Ocean. Nature 446:1070-1074

Bogan RAJ, Ohde S, Arakaki T, Mori I, McLeod CW (2009) Changes in rainwater $\mathrm{pH}$ associated with increasing atmospheric carbon dioxide after the industrial revolution. Water Air Soil Pollut 196:263-271

Boyd PW (2009) Ocean iron cycle. In: Le Quere C, Slatzman ES (eds) Surface ocean lower atmosphere processes. AGU Monographs 187. AGU Publications, Washington, DC, p 161-180

Boyd PW, Doney SC (2003) The impact of climate change and feedback processes on the ocean carbon cycle. In: Fasham MJR (ed) Ocean biogeochemistry. SpringerVerlag, Berlin, p 157-193

Boyd PW, Ellwood MJ (2010) The biogeochemical cycle of iron in the ocean. Nat Geosci 3:675-682

> Boyd PW, Doney SC, Strzepek R, Dusenberry J, Lindsay K, Fung I (2008) Climate-mediated changes to mixed-layer properties in the Southern Ocean: assessing the phytoplankton response. Biogeosciences 5:847-864

Boyd PW, Strzepek R, Fu F, Hutchins DA (2010) Environmental control of open-ocean phytoplankton groups: now and in the future. Limnol Oceanogr 55:1353-1376

> Boyd PW, Arrigo KR, Strzepek R, van Dijken GL (2012) Mapping phytoplankton iron utilization: insights into Southern Ocean supply mechanisms. J Geophys Res 117 , C06009, doi:10.1029/2011JC007726

Breitbarth E, Gelting J, Walve J, Hoffmann LJ, Turner DR, Hassellöv M, Ingri J (2009) Dissolved iron (II) in the Baltic Sea surface water and implications for cyanobacterial bloom development. Biogeosciences 6:2397-2420

> Breitbarth E, Achterberg EP, Ardelan MV, Baker AR and others (2010a) Iron biogeochemistry across marine systems - progress from the past decade. Biogeosciences 7:1075-1097

> Breitbarth E, Bellerby RJ, Neill CC, Ardelan MV and others (2010b) Ocean acidification affects iron speciation during a coastal seawater mesocosm experiment. Biogeosciences 7:1065-1073

Bruland KW (1989) Complexation of zinc by natural organic ligands in the central North Pacific. Limnol Oceanogr 34:269-285

Bruland KW (1992) Complexation of cadmium by natural organic ligands in the central North Pacific. Limnol Oceanogr 37:1008-1017

Buitenhuis ET, Timmermans KR, de Baar HJW (2003) Zinc- bicarbonate colimitation of Emiliania huxleyi. Limnol Oceanogr 48:1575-1582

Caldeira K, Wickett ME (2003) Anthropogenic carbon and ocean $\mathrm{pH}$. Nature 425:365

Coale KH, Bruland KW (1988) Copper complexation in the Northeast Pacific. Limnol Oceanogr 33:1084-1101

> Comiso JC (2012) Large decadal decline of the Arctic multiyear ice cover. J Clim 25:1176-1193

> Croot PL, Moffett JW, Brand LE (2000) Production of extracellular $\mathrm{Cu}$ complexing ligands by eucaryotic phytoplankton in response to $\mathrm{Cu}$ stress. Limnol Oceanogr 45:619-627

> Croot PL, Laan P, Nishioka J, Strass V and others (2005) Spatial and temporal distribution of $\mathrm{Fe}(\mathrm{II})$ and $\mathrm{H}_{2} \mathrm{O}_{2}$ during EisenEx, an open ocean mesoscale iron enrichment. Mar Chem 95:65-88

> Cullen JT (2006) On the nonlinear relationship between dissolved cadmium and phosphate in the modern ocean: Could chronic iron limitation of phytoplankton growth cause the kink? Limnol Oceanogr 51:1369-1380

Cullen JT, Lane TW, Morel FMM, Sherrell RM (1999) Modulation of cadmium uptake in phytoplankton by seawater $\mathrm{CO}_{2}$ concentration. Nature 402:165-167

Cullen JT, Chase Z, Coale KH, Fitzwater SE, Sherrell RM (2003) Effect of iron limitation on the cadmium to phosphorus ratio of natural phytoplankton assemblages from the Southern Ocean. Limnol Oceanogr 48:1079-1087

$>$ Delisle G (2007) Near-surface permafrost degradation: how severe during the 21st century? Geophys Res Lett 34, L09503, doi:10.1029/2007GL029323

> Desboeufs KV, Losno R, Colin JL (2001) Factors influencing aerosol solubility during cloud processes. Atmos Environ 35:3529-3537

Doney SC (2006) Plankton in a warmer world. Nature 444:695-696

Doney SC, Balch WM, Fabry VJ, Feely RA (2009a) Ocean acidification: a critical emerging problem for the ocean sciences. Oceanography 22:16-25

Doney SC, Fabry VJ, Feely RA, Kleypas JA (2009b) Ocean acidification: the other $\mathrm{CO}_{2}$ problem. Annu Rev Mar Sci $1: 169-192$

$>$ Dupont CL, Ahner BA (2005) Effects of copper, cadmium, and zinc on the production and exudation of thiols by Emiliania huxleyi. Limnol Oceanogr 50:508-515

Dupont CL, Goepfert TJ, Lo P, Wei LP, Ahnerz BA (2004) Diurnal cycling of glutathione in marine phytoplankton: field and culture studies. Limnol Oceanogr 49:991-996

> Engel A, Dellile B, Jacquet S, Riebesell U, Rochelle-Newall E, Terbrüggen A, Zondervan I (2004) Transparent exopolymer particles and dissolved organic carbon production by Emiliania huxleyi exposed to different $\mathrm{CO}_{2}$ concentrations: a mesocosm experiment. Aquat Microb Ecol 34:93-104

Feely RA, Sabine CL, Lee K, Berelson W, Kleypas J, Fabry VJ, Millero FJ (2004) Impact of anthropogenic $\mathrm{CO}_{2}$ on the $\mathrm{CaCO}_{3}$ system in the oceans. Science 305:362-366

Feng Y, Hare CE, Rose JM, Handy SM and others (2010) Interactive effects of iron, irradiance and $\mathrm{CO}_{2}$ on Ross Sea phytoplankton. Deep-Sea Res I 57:368-383

Fitzwater SE, Johnson KS, Gordon RM, Coale KH, Smith WO Jr (2000) Trace metal concentrations in the Ross Sea and their relationship with nutrients and phytoplankton growth. Deep-Sea Res II 47:3159-3179

Fu FX, Mulholland MR, Garcia NS, Beck A and others (2008) Interactions between changing $\mathrm{pCO}_{2}, \mathrm{~N}_{2}$ fixation, 
and Fe limitation in the marine unicellular cyanobacterium Crocosphaera. Limnol Oceanogr 53:2472-2484

Gattuso JP, Hansson L (eds) (2011) Ocean acidification. Oxford University Press, New York, NY

> Grossart HP, Allgaier M, Passow U, Riebesell U (2006) Testing the effect of $\mathrm{CO}_{2}$ concentration on the dynamics of marine heterotrophic bacterioplankton. Limnol Oceanogr 51:1-11

Gruber N (2011) Warming up, turning sour, losing breath: ocean biogeochemistry under global change. Philos Trans R Soc Lond A Math Phys Eng Sci 369:1980-1996

Hendry KR, Rickaby REM, de Hoog JCM, Weston K, Rehkämper M (2008) Cadmium and phosphate in coastal Antarctic seawater: implications for Southern Ocean nutrient cycling. Mar Chem 112:149-157

Hoffmann LJ, Breitbarth E, McGraw CM, Law CS, Hunter $\mathrm{KA}$ (in press) A trace-metal clean $\mathrm{pH}$ controlled incubator system for ocean acidification research. Limnol Oceanogr Methods

Hölemann JA, Schirmacher M, Kassens H, Prange A (1999) Geochemistry of surficial and ice-rafted sediments from the Laptev Sea (Siberia). Estuar Coast Shelf Sci 49:45-59

> Hunter KA, Liss PS, Surapipith V, Dentener F and others (2011) Impacts of anthropogenic $\mathrm{SO}_{\mathrm{x}}, \mathrm{NO}_{\mathrm{x}}$ and $\mathrm{NH}_{3}$ on acidification of coastal waters and shipping lanes. Geophys Res Lett 38, L13602, doi:10.1029/2011GL047720

Hutchins DA, Witter AE, Butler A, Luther GWI (1999) Competition among marine phytoplankton for different chelated iron species. Nature 400:858-861

> Hutchins DA, Fu FX, Zhang Y, Warner ME and others (2007) $\mathrm{CO}_{2}$ control of Trichodesmium $\mathrm{N}_{2}$ fixation, photosynthesis, growth rates, and elemental ratios: implications for past, present, and future ocean biogeochemistry. Limnol Oceanogr 52:1293-1304

> Hutchins DA, Mulholland MR, Fu FX (2009) Nutrient cycles and marine microbes in a $\mathrm{CO}_{2}$-enriched ocean. Oceanography 22:128-145

$>$ Iles AC, Gouhier TC, Menge BA, Stewart JS, Haupt AJ, Lynch MC (2012) Climate-driven trends and ecological implications of event-scale upwelling in the California Current System. Glob Change Biol 18:783-796

$>$ Jacobson MZ (2005) Studying ocean acidification with conservative, stable numerical schemes for nonequilibrium air-ocean exchange and ocean equilibrium chemistry. J Geophys Res 110, D07302, doi:10.1029/2004JD005220

> Jickells TD, An ZS, Andersen KK, Baker AR and others (2005) Global iron connections between desert dust, ocean biogeochemistry, and climate. Science 308:67-71

King AL, Sanudo-Wilhelmy SA, Leblanc K, Hutchins DA, Fu FX (2011) $\mathrm{CO}_{2}$ and vitamin $\mathrm{B}_{12}$ interactions determine bioactive trace metal requirements of a subarctic Pacific diatom. ISME J 5:1388-1396

> Klunder MB, Bauch D, Laan P, de Baar HJW, van Heuven S, Ober S (2012) Dissolved iron in the Arctic shelf seas and surface waters of the central Arctic Ocean: impact of Arctic river water and ice-melt. J Geophys Res 117, C01027, doi:10.1029/2011JC007133

Kritzberg ES, Duarte CM, Wassmann P (2010) Changes in Arctic marine bacterial carbon metabolism in response to increasing temperature. Polar Biol 33:1673-1682

> Kuma K, Nakabayashi S, Matsunaga K (1995) Photoreduction of Fe(III) by hydroxycarboxylic acids in seawater. Water Res 29:1559-1569

Kuma K, Nishioka J, Matsunaga K (1996) Controls of iron(III) hydroxide solubility in seawater: the influence of
$\mathrm{pH}$ and natural organic chelators. Limnol Oceanogr 41:396-407

Kustka A, Sanudo-Wilhelmy S, Carpenter EJ, Capone DG, Raven JA (2003) A revised estimate of the iron use efficiency of nitrogen fixation, with special reference to the marine cyanobacterium Trichodesmium spp. (Cyanophyta). J Phycol 39:12-25

- Lacoue-Labarthe T, Martin S, Oberhansli F, Teyssie JL, Markich S, Ross J, Bustamante P (2009) Effects of increased $\left.p \mathrm{CO}_{2}\right)$ and temperature on trace element ( $\mathrm{Ag}, \mathrm{Cd}$ and $\mathrm{Zn}$ ) bioaccumulation in the eggs of the common cuttlefish, Sepia officinalis. Biogeosciences $6: 2561-2573$

> Lacoue-Labarthe T, Reveillac E, Oberhansli F, Teyssie JL, Jeffree R, Gattuso JP (2011) Effects of ocean acidification on trace element accumulation in the early-life stages of squid Loligo vulgaris. Aquat Toxicol 105:166-176

> Lacoue-Labarthe T, Martin S, Oberhansli F, Teyssie JL, Jeffree R, Gattuso JP, Bustamante P (2012) Temperature and $\left.p \mathrm{CO}_{2}\right)$ effect on the bioaccumulation of radionuclides and trace elements in the eggs of the common cuttlefish, Sepia officinalis. J Exp Mar Biol Ecol 413:45-49

> Laës A, Blain S, Laan P, Ussher SJ, Achterberg EP, Treguer $\mathrm{P}$, de Baar HJW (2007) Sources and transport of dissolved iron and manganese along the continental margin of the Bay of Biscay. Biogeosciences 4:181-194

> Landry MR, Barber RT, Bidigare RR, Chai F and others (1997) Iron and grazing constraints on primary production in the central equatorial Pacific: an EqPac synthesis. Limnol Oceanogr 42:405-418

> Lane ES, Jang K, Cullen JT, Maldonado MT (2008) The interaction between inorganic iron and cadmium uptake in the marine diatom Thalassiosira oceanica. Limnol Oceanogr 53:1784-1789

> Lane ES, Semeniuk DM, Strzepek RF, Cullen JT, Maldonado MT (2009) Effects of iron limitation on intracellular cadmium of cultured phytoplankton: implications for surface dissolved cadmium to phosphate ratios. Mar Chem 115:155-162

> Lannuzel D, Bowie AR, van der Merwe PC, Townsend AT, Schoemann V (2011) Distribution of dissolved and particulate metals in Antarctic sea ice. Mar Chem 124:134-146

Law CS, Breitbarth E, Hoffmann LJ, McGraw CM and others (2012) No stimulation of nitrogen fixation by nonfilamentous diazotrophs under elevated $\mathrm{CO}_{2}$ in the South Pacific. Glob Change Biol 18:3004-3014

> Lawrence DM, Slater AG, Tomas RA, Holland MM, Deser C (2008) Accelerated Arctic land warming and permafrost degradation during rapid sea ice loss. Geophys Res Lett 35, L11506, doi:10.1029/2008GL033985

Lemke P, Ren J, Alley RB, Allison I and others (2007) Observations: changes in snow, ice and frozen ground. In: Solomon S, Qin D, Manning M, Chen Z and others (eds) Climate change 2007: the physical science basis. Contribution of Working Group I to the Fourth Assessment Report of the Intergovernmental Panel on Climate Change. Cambridge University Press, Cambridge and New York, NY, p 337-383

Levitan O, Rosenberg G, Setlik I, Setlikova E and others (2007) Elevated $\mathrm{CO}_{2}$ enhances nitrogen fixation and growth in the marine cyanobacterium Trichodesmium. Glob Change Biol 13:531-538

> Lin $\mathrm{H}$, Rauschenberg $\mathrm{S}$, Hexel CR, Shaw TJ, Twining BS (2011) Free-drifting icebergs as sources of iron to the Weddell Sea. Deep-Sea Res II 58:1392-1406 
Liu X, Millero FJ (2002) The solubility of iron in seawater. Mar Chem 77:43-54

Liu J, Weinbauer MG, Maier C, Dai M, Gattuso JP (2010) Effect of ocean acidification on microbial diversity and on microbe-driven biogeochemistry and ecosystem functioning. Aquat Microb Ecol 61:291-305

Louis Y, Garnier C, Lenoble V, Omanovic D, Mounier S, Pizeta I (2009) Characterisation and modelling of marine dissolved organic matter interactions with major and trace cations. Mar Environ Res 67:100-107

- Mackey DJ, O'Sullivan JE, Watson RJ (2002) Iron in the western Pacific: a riverine or hydrothermal source for iron in the Equatorial Undercurrent? Deep-Sea Res I 49:877-893

> Mahowald NM, Luo C (2003) A less dusty future? Geophys Res Lett 30, 1903, doi:10.1029/2003GL017880

Mahowald NM, Baker AR, Bergametti G, Brooks N and others (2005) Atmospheric global dust cycle and iron inputs to the ocean. Global Biogeochem Cycles 19, GB4025, doi:10.1029/2004GB002402

Mahowald NM, Engelstaedter S, Luo C, Sealy A and others (2009) Atmospheric iron deposition: global distribution, variability, and human perturbations. Annu Rev Mar Sci 1:245-278

Maldonado M, Price NM (1999) Utilization of iron bound to strong organic ligands by plankton communities in the subarctic Pacific Ocean. Deep-Sea Res II 46:2447-2473

- Maldonado MT, Boyd PW, Harrison PJ, Price NM (1999) Colimitation of phytoplankton growth by light and Fe during winter in the NE subarctic Pacific Ocean. Deep-Sea Res II 46:2475-2485

Maldonado MT, Allen AE, Chong JS, Lin K, Leus D, Karpenko N, Harris SL (2006) Copper-dependent iron transport in coastal and oceanic diatoms. Limnol Oceanogr 51:1729-1743

> Marsland SJ, Church JA, Bindoff NL, Williams GD (2007) Antarctic coastal polynya response to climate change. J Geophys Res 112, C07009, doi:10.1029/2005JC003291

Martin JH (1990) Glacial-interglacial $\mathrm{CO}_{2}$ change: the iron hypothesis. Paleoceanography 5:1-13

> Measures CI (1999) The role of entrained sediments in sea ice in the distribution of aluminium and iron in the surface waters of the Arctic Ocean. Mar Chem 68:59-70

Meehl GA, Stocker TF, Collins WD, Friedlingstein P and others (2007) Global climate projections. In: Solomon S, Qin D, Manning M, Chen Z and others (eds) Climate change 2007: the physical science basis. Contribution of Working Group I to the Fourth Assessment Report of the Intergovernmental Panel on Climate Change. Cambridge University Press, Cambridge and New York, NY, p 747-845

Millero FJ (2001) Speciation of metals in natural seawater. Geochem Trans 2:56-64

Millero FJ, Sharma VK, Karn B (1991) The rate of reduction of copper(II) with hydrogen-peroxide in seawater. Mar Chem 36:71-83

Millero FJ, Woosley R, Ditrolio B, Waters J (2009) Effect of ocean acidification on the speciation of metals in seawater. Oceanography 22:72-85

Milne A, Landing W, Bizimis M, Morton P (2010) Determination of $\mathrm{Mn}, \mathrm{Fe}, \mathrm{Co}, \mathrm{Ni}, \mathrm{Cu}, \mathrm{Zn}, \mathrm{Cd}$ and $\mathrm{Pb}$ in seawater using high resolution magnetic sector inductively coupled mass spectrometry (HR-ICP-MS). Anal Chim Acta 665:200-207

Moffett JW, Brand LE (1996) Production of strong, extracel- lular $\mathrm{Cu}$ chelators by marine cyanobacteria in response to Cu stress. Limnol Oceanogr 41:388-395

Moffett JW, Zika RG (1987) Reaction kinetics of hydrogen peroxide with copper and iron in seawater. Environ Sci Technol 21:804-810

Moffett JW, Zika RG (1988) Measurement of copper(I) in surface waters of the subtropical Atlantic and Gulf of Mexico. Geochim Cosmochim Acta 52:1849-1857

Morel FMM, Price NM (2003) The biogeochemical cycles of trace metals in the oceans. Science 300:944-947

Morel FMM, Reinfelder JR, Roberts SB, Chamberlain CP, Lee JG, Yee D (1994) Zinc and carbon co-limitation of marine phytoplankton. Nature 369:740-742

> Morel FMM, Kustka AB, Shaked Y (2008) The role of unchelated $\mathrm{Fe}$ in the iron nutrition of phytoplankton. Limnol Oceanogr 53:400-404

> Olgun N, Duggen S, Croot PL, Delmelle P and others (2011) Surface ocean iron fertilization: the role of airborne volcanic ash from subduction zone and hotspot volcanoes and related iron fluxes into the Pacific Ocean. Global Biogeochem Cycles 25, GB4001, doi:10.1029/2009GB 003761

> Orr JC, Fabry VJ, Aumont O, Bopp L and others (2005) Anthropogenic ocean acidification over the twenty-first century and its impact on calcifying organisms. Nature 437:681-686

> Peers G, Quesnel SA, Price NM (2005) Copper requirements for iron acquisition and growth of coastal and oceanic diatoms. Limnol Oceanogr 50:1149-1158

> Perovich DK, Richter-Menge JA (2009) Loss of sea ice in the Arctic. Annu Rev Mar Sci 1:417-441

Piontek J, Lunau M, Händel N, Borchard C, Wurst M, Engel A (2010) Acidification increases microbial polysaccharide degradation in the ocean. Biogeosciences 7 : 1615-1624

Price NM, Morel FMM (1990) Cadmium and cobalt substitution for zinc in a marine diatom. Nature 344:658-660

Quigg A, Finkel ZV, Irwin AJ, Rosenthal Y and others (2003) The evolutionary inheritance of elemental stoichiometry in marine phytoplankton. Nature 425:291-294

Rabenstein DL (1989) Metal complexes of glutathione and their biological significance. In: Dolphin D, Poutson R, Avramovic O (eds) Glutathione: chemical, biochemical, and medical aspects. John Wiley \& Sons, New York, NY, p 147-186

Rahmstorf S, Ganopolski A (1999) Long-term global warming scenarios computed with an efficient coupled climate model. Clim Change 43:353-367

Ravi S, D'Odorico P, Breshears DD, Field JP and others (2011) Aeolian processes and the biosphere. Rev Geophys 49, RG3001, doi:10.1029/2010RG000328

Rember RD, Trefry JH (2004) Increased concentrations of dissolved trace metals and organic carbon during snowmelt in rivers of the Alaskan arctic. Geochim Cosmochim Acta 68:477-489

Riebesell U, Fabry VJ, Hansson L, Gattuso JP (eds) (2010) Guide to best practices for ocean acidification research and data reporting. Publications Office of the European Union, Luxembourg

> Rose JM, Feng Y, DiTullio GR, Dunbar RB and others (2009) Synergistic effects of iron and temperature on Antarctic phytoplankton and microzooplankton assemblages. Biogeosciences 6:3131-3147

Rue EL, Bruland KW (1995) Complexation of iron(III) by natural organic ligands in the Central North Pacific as 
determined by a new competitive ligand equilibration/ adsorptive cathodic stripping voltammetric method. Mar Chem 50:117-138

Saito MA, Moffett JW (2001) Complexation of cobalt by natural organic ligands in the Sargasso Sea as determined by a new high-sensitivity electrochemical cobalt speciation method suitable for open ocean work. Mar Chem 75:49-68

Saito MA, Rocap G, Moffett JW (2005) Production of cobalt binding ligands in a Synechococcus feature at the Costa Rica upwelling dome. Limnol Oceanogr 50:279-290

Salisbury FB, Ross CW (1992) Plant physiology. Wadsworth Publishing, Belmont, CA

Salmon TP, Rose AL, Neilan BA, Waite TD (2006) The FeL model of iron acquisition: nondissociative reduction of ferric complexes in the marine environment. Limnol Oceanogr 51:1744-1754

Sander SG, Koschinsky A (2011) Metal flux from hydrothermal vents increased by organic complexation. Nat Geosci 4:145-150

Sander S, Ginon L, Anderson B, Hunter KA (2007) Comparative study of organic $\mathrm{Cd}$ and $\mathrm{Zn}$ complexation in lake waters - seasonality, depth and $\mathrm{pH}$ dependence. Environ Chem 4:410-423

Schofield O, Ducklow HW, Martinson DG, Meredith MP, Moline MA, Fraser WR (2010) How do polar marine ecosystems respond to rapid climate change? Science 328 : 1520-1523

Sedwick PN, Sholkovitz ER, Church TM (2007) Impact of anthropogenic combustion emissions on the fractional solubility of aerosol iron: evidence from the Sargasso Sea. Geochem Geophys Geosyst 8, Q10Q06, doi:10.1029/ 2007GC001586

Semeniuk DM, Cullen JT, Johnson WK, Gagnon K, Ruth TJ, Maldonado MT (2009) Plankton copper requirements and uptake in the subarctic Northeast Pacific Ocean. Deep-Sea Res I 56:1130-1142

Shaked Y (2008) Iron redox dynamics in the surface waters of the Gulf of Aqaba, Red Sea. Geochim Cosmochim Acta 72:1540-1554

Shaked Y, Kustka AB, Morel FMM (2005) A general kinetic model for iron acquisition by eukaryotic phytoplankton. Limnol Oceanogr 50:872-882

Shaw TJ, Raiswell R, Hexel CR, Vu HP, Moore WS, Dudgeon R, Smith KL (2011) Input, composition, and potential impact of terrigenous material from free-drifting icebergs in the Weddell Sea. Deep-Sea Res II 58:1376-1383

> Shi D, Xu Y, Hopkinson BM, Morel FMM (2010) Effect of ocean acidification on iron availability to marine phytoplankton. Science 327:676-679

Sholkovitz ER, Sedwick PN, Church TM (2009) Influence of anthropogenic combustion emissions on the deposition of soluble aerosol iron to the ocean: empirical estimates for island sites in the North Atlantic. Geochim Cosmochim Acta 73:3981-4003

Sillén LG, Martell AE (1971) Stability constants of metal ion complexes. Special Publication No. 25. Chemical Society, London

Smetacek V, Klaas C, Strass VH, Assmy P and others (2012) Deep carbon export from a Southern Ocean iron-fertilized diatom bloom. Nature 487:313-319

Stier P, Feichter J, Roeckner E, Kloster S, Esch M (2006) The evolution of the global aerosol system in a transient climate simulation from 1860 to 2100. Atmos Chem Phys 6:3059-3076
Stramma L, Johnson GC, Sprintall J, Mohrholz V (2008) Expanding oxygen-minimum zones in the tropical oceans. Science 320:655-658

Strasdeit H, Duhme AK, Kneer R, Zenk MH, Hermes C, Nolting HF (1991) Evidence for discrete Cd(SCys) ${ }_{4}$ units in cadmium phytochelatin complexes from EXAFS spectroscopy. J Chem Soc Lond Chem Comm:1129-1130

Stumm W, Morgan JJ (1996) Aquatic chemistry. Wiley, New York, NY

Sunda WG (2001) Bioavailability and bioaccumulation of iron in the sea. In: Turner DR, Hunter KA (eds) The biogeochemistry of iron in seawater, Vol 7. John Wiley \& Sons, Chichester, p 41-84

Sunda WG (2010) Iron and the carbon pump. Science 327 : 654-655

Sunda WG, Hanson AK (1987) Measurement of free cupric ion concentration in seawater by a ligand competition technique involving copper sorption onto C-18 SEP-PAK cartridges. Limnol Oceanogr 32:537-551

> Sunda WG, Huntsman SA (1983) Effect of competitive interactions between manganese and copper on cellular manganese and growth in estuarine and oceanic species of the diatom Thalassiosira. Limnol Oceanogr 28:924-934

Sunda WG, Huntsman SA (1991) The use of chemiluminescence and ligand competition with EDTA to measure copper concentration and speciation in seawater. Mar Chem 36:137-163

Sunda WG, Huntsman SA (1994) Photoreduction of manganese oxides in seawater. Mar Chem 46:133-152

Sunda WG, Huntsman SA (1996) Antagonisms between cadmium and zinc toxicity and manganese limitation in a coastal diatom. Limnol Oceanogr 41:373-387

> Sunda WG, Huntsman SA (1997) Interrelated influence of iron, light and cell size on marine phytoplankton growth. Nature 390:389-392

Sunda WG, Huntsman SA (2000) Effect of Zn, Mn, and Fe on $\mathrm{Cd}$ accumulation in phytoplankton: implications for oceanic Cd cycling. Limnol Oceanogr 45:1501-1516

Sunda WG, Huntsman SA (2003) Effect of pH, light, and temperature on Fe-EDTA chelation and Fe hydrolysis in seawater. Mar Chem 84:35-47

Sunda WG, Huntsman SA (2011) Interactive effects of light and temperature on iron limitation in a marine diatom: implications for marine productivity and carbon cycling. Limnol Oceanogr 56:1475-1488

- Tegen I, Werner M, Harrison SP, Kohfeld KE (2004) Relative importance of climate and land use in determining present and future global soil dust emission. Geophys Res Lett 31, L05105, doi:10.1029/2003GL019216

> Tokinaga H, Xie SP, Timmermann A, McGregor S, Ogata T, Kubota H, Okumura YM (2012) Regional patterns of tropical Indo-Pacific climate change: evidence of the Walker Circulation weakening. J Clim 25:1689-1710

Tortell PD, Payne CD, Li YY, Trimborn S and others (2008) $\mathrm{CO}_{2}$ sensitivity of Southern Ocean phytoplankton. Geophys Res Lett 35, L04605, doi:10.1029/2007GL032583

Tovar-Sanchez A, Sanudo-Wilhelmy SA, Kustka AB, Agusti S and others (2006) Effects of dust deposition and river discharges on trace metal composition of Trichodesmium spp. in the tropical and subtropical North Atlantic Ocean. Limnol Oceanogr 51:1755-1761

Tsunematsu N, Kuze H, Sato T, Hayasaki M, Cui FF, Kondoh A (2011) Potential impact of spatial patterns of future atmospheric warming on Asian dust emission. Atmos Environ 45:6682-6695 
Turnewitsch R, Pohl C (2010) An estimate of the efficiency of the iron- and manganese-driven dissolved inorganic phosphorus trap at an oxic/euxinic water column redoxcline. Global Biogeochem Cycles 24, GB4025, doi:10.1029/ 2010GB003820

Ussher SJ, Worsfold PJ, Achterberg EP, Laes A, Blain S, Laan P, de Baar HJW (2007) Distribution and redox speciation of dissolved iron on the European continental margin. Limnol Oceanogr 52:2530-2539

> Vahedpour M, Zolfaghari F (2011) Mechanistic study on the atmospheric formation of acid rain base on the sulfur dioxide. Struct Chem 22:1331-1338

van der Merwe P, Lannuzel D, Bowie AR, Meiners KM (2011) High temporal resolution observations of spring fast ice melt and seawater iron enrichment in East Antarctica. J Geophys Res 116, G03017, doi:10.1029/2010JG001628

> Vaqué D, Guadayol Ò, Peters F, Felipe J, Malits A, PedrósAlió C (2009) Differential response of grazing and bacterial heterotrophic production to experimental warming in Antarctic waters. Aquat Microb Ecol 54:101-112

Wagener T, Guieu C, Losno R, Bonnet S, Mahowald N (2008) Revisiting atmospheric dust export to the Southern Hemisphere ocean: biogeochemical implications. Global Biogeochem Cycles 22, GB2006, doi:10.1029/2007GB 002984

Wassmann P, Reigstad M (2011) Future Arctic Ocean seasonal ice zones and implications for pelagic-benthic coupling. Oceanography 24:220-231

Submitted: March 14, 2012; Accepted: September 28, 2012
Wassmann P, Duarte CM, Agusti S, Sejr MK (2011) Footprints of climate change in the Arctic marine ecosystem. Glob Change Biol 17:1235-1249

Weinbauer MG, Mari X, Gattuso JP (2011) Effects of ocean acidification on the diversity and activity of heterotrophic marine microorganisms. In: Gattuso JP, Hansson L (eds) Ocean acidification. Oxford University Press, New York, NY, p 83-98

- Wells ML, Trick CG, Cochlan WP, Hughes MP, Trainer VL (2005) Domoic acid: the synergy of iron, copper, and the toxicity of diatoms. Limnol Oceanogr 50:1908-1917

> Whitney FA, Freeland HJ, Robert M (2007) Persistently declining oxygen levels in the interior waters of the eastern subarctic Pacific. Prog Oceanogr 75:179-199

- Woodward S, Roberts DL, Betts RA (2005) A simulation of the effect of climate change-induced desertification on mineral dust aerosol. Geophys Res Lett 32, L18810, doi: 10.1029/2005GL023482

Xu Y, Shi D, Aristilde L, Morel FMM (2012) The effect of $\mathrm{pH}$ on the uptake of zinc and cadmium in marine phytoplankton: possible role of weak ligands. Limnol Oceanogr 57:293-304

Yamamoto-Kawai M, Carmack E, McLaughlin F (2006) Nitrogen balance and Arctic throughflow. Nature 443:43

Yamamoto-Kawai M, McLaughlin FA, Carmack EC, Nishino S, Shimada K (2009) Aragonite undersaturation in the Arctic Ocean: effects of ocean acidification and sea ice melt. Science 326:1098-1100

Proofs received from author(s): November 12, 2012 